\title{
Pengaruh Pemberian Suplemen dan Teat Dipping Temulawak (Curcuma xanthorriza Roxb) terhadap Konsumsi Pakan dan Produksi Susu Sapi Laktasi Mastitis Subklinis
}

\author{
The Effect of Temulawak (Curcuma xanthorriza Roxb) Supplementation and Teat Dipping on \\ Feed Intake and Milk Production of Subclinical Mastitis Cows
}

\author{
N. E. Kharisa, R. Hartanto dan D. W. Harjanti
}

Fakultas Peternakan dan Pertanian, Universitas Diponegoro

Jl. Prof. Soedarto, SH Tembalang 50275, Semarang, Jawa Tengah Indonesia

Corresponding email : nadiyaendahkharisa9g@gmail.com

\begin{abstract}
This research was aimed to evaluate the effect of temulawak (Curcuma xanthorriza Roxb) suplementation and antiseptic teat dipping treatment of temulawak on feed intake and milk production of subclinical mastitis cows. The materials were used 12 Friesian Holstein (FH) lactating dairy cows with subclinical mastitis, in period 3-5 and 5-6 month of lactation with an average body weight of $466.49 \pm 44.99(\mathrm{CV}=9,75 \%) \mathrm{kg}$ and $6.90 \pm 2.70(\mathrm{CV}=$ $39.34 \%$ ) liter of milk production. A block randomized design with 4 treatments and 3 groups based on milk production (low, medium and high milk production) were used. The treatments applied were $\mathrm{T}_{0}=$ basal diet without treatment $\mathrm{T}_{1}=\mathrm{T}_{0}+$ temulawak supplement $1 \%$ dry matter requirement, $\mathrm{T}_{2}=\mathrm{T}_{0}+$ temulawak antiseptic teat dipping treatment and $\mathrm{T}_{3}=\mathrm{T}_{0}+$ supplement $1 \%$ dry matter requirement + temulawak antiseptic teat dipping treatment. The parameters observed were dry matter (DM) intake and milk production. The statistic test using ANOVA 5\%. Data showed that treatments did not affect on DM intake and milk production. In conclusion, temulawak supplementation and antiseptic teat dipping did not increase DM intake and milk production of subclinical mastitis cows.
\end{abstract}

Key words : Mastitis cow, temulawak, teat dipping, feed intake, milk production

\begin{abstract}
ABSTRAK
Penelitian ini bertujuan untuk mengkaji pengaruh pemberian suplemen dan antiseptik teat dipping temulawak terhadap konsumsi pakan dan produksi susu sapi laktasi penderita mastitis subklinis. Materi penelitian adalah 12 ekor sapi perah Friesian Holstein (FH) penderita mastitis subklinis, laktasi ke 3-5 dan bulan laktasi ke 5-6 dengan rata-rata bobot badan 466,49 $\pm 44,99(\mathrm{CV}=9,75 \%) \mathrm{kg}$ dan produksi susu awal 6,90 $\pm 2,70(\mathrm{CV}=39,34 \%)$ liter. Penelitian menggunakan rancangan acak kelompok dengan 4 perlakuan dan 3 kelompok yang didasarkan produksi susu yaitu rendah, sedang dan tinggi. Perlakuan yang diterapkan yaitu $\mathrm{T}_{0}=\operatorname{tanpa}$ perlakuan, $\mathrm{T}_{1}=$ Pakan basal + suplemen temulawak $1 \%$ kebutuhan $\mathrm{BK}, \mathrm{T}_{2}=$ Pakan basal + antiseptik teat dipping temulawak dan $\mathrm{T}_{3}=$ Pakan basal +suplemen temulawak $1 \%$ kebutuhan $\mathrm{BK}+$ antiseptik teat dipping temulawak. Parameter penelitian ini yaitu konsumsi bahan kering pakan dan produksi susu. Data yang diperoleh dianalisis dengan analisis ragam (ANOVA) pada taraf signifikasi 5\%. Hasil penelitian menunjukkan bahwa perlakuan tidak berpengaruh nyata terhadap konsumsi BK dan produksi susu. Simpulan dari penelitian adalah pemberian suplemen $1 \%$ kebutuhan BK dan antiseptik teat dipping temulawak belum mampu meningkatkan konsumsi BK dan produksi susu sapi perah laktasi penderita mastitis subklinis.
\end{abstract}

Kata Kunci : Sapi perah, temulawak, teat dipping, konsumsi, produksi susu

\section{PENDAHULUAN}

Sapi perah merupakan ternak penghasil susu yang dominan dibandingkan dengan ruminansia lain. Susu sebagai penunjang kebutuhan masyarakat yang kaya protein dan lemak hewani. Kebutuhan susu di Indonesia terus mengalami peningkatan mencapai 16,84 $\mathrm{kg} / \mathrm{kapita} / \mathrm{tahun}$ atau sekitar 977,67 ribu ton/tahun (Pusat Data Sistem Informatik Kementrian Pertanian, 2017), akan tetapi tidak diimbangi oleh pasokan susu di dalam negeri. Di Indonesia peternakan sapi perah didominasi oleh peternakan rakyat yang rata-rata produksi susu hanya 10 - 12 liter/hari. Produksi tersebut belum mampu memenuhi kebutuhan masyarakat, sehingga masih dilakukan impor susu dari luar negeri sebanyak 73,84\% (Pusat Data Sistem Informatik Kementrian Pertanian, 2017).

Salah satu faktor yang menyebabkan rendahnya produksi susu yaitu pemberian pakan yang tidak sesuai kebutuhan ternak baik dari segi 
kuantitas maupun kualitas dan adanya penyakit. Penyakit yang sering menyerang sapi perah yaitu mastitis. Mastitis merupakan peradangan pada ambing hewan mamalia yang disebabkan infeksi intramammary oleh bakteri patogen yang menyebabkan penurunan produksi dan kualitas susu (Harjanti et al., 2018). Mastitis ada dua yaitu mastitis klinis dan mastitis subklinis. Mastitis klinis dapat diketahui gejalanya pada bagian eskterior ambing dengan perabaan seperti pembengkakan, berwarna merah dan panas, akan tetapi pada mastitis subklinis tidak dapat diketahui gejalanya (Mahpudin et al., 2017). Mastitis subklinis hanya dapat diketahui dengan pengujian kualitas susu seperti uji California Mastitis Test (CMT).

Upaya yang dapat dilakukan untuk mencegah mastitis yaitu dengan teat dipping atau pencelupan puting setelah proses pemerahan menggunakan bahan antiseptik seperti iodine dan chlorine atau dengan pemberian suplemen untuk meningkatkan daya tahan tubuh. Penggunaan antiseptik sintetis dapat menimbulkan iritasi dan residu pada susu sehingga diperlukan bahan pengganti. Alternatif yang digunakan dapat berasal dari bahan alami yang mengandung senyawa antibakteri atau antiradang misalnya temulawak. Temulawak (Curcuma xanthorriza Roxb) merupakan tanaman herbal yang mengandung senyawa antibakteri, antiinflamasi dan dapat meningkatkan daya tahan tubuh ternak dengan memperbanyak sel CD4, selain itu temulawak juga tidak meninggalkan residu pada tubuh (Alipin et al., 2016 ; Harjanti et al., 2019).

Temulawak mengandung dua senyawa aktif yaitu minyak atsiri dan kurkuminoid. Minyak atsiri dapat meningkatkan nafsu makan (Raharjo, 2010), karena sifat antiinflamasi pada temulawak dapat meningkatkan populasi mikroba rumen dan menekan mikroba patogen sehingga akan mempercepat kerja usus halus (Lucy et al., 2017). Kurkumin dalam temulawak melindungi membran kelenjar ambing dari infeksi bakteri dan sebagai substan yang menyerupai hormon prolaktin dan oksitosin (Harjanti et al., 2019).

Penggunaan temulawak sebagai teat dipping akan membantu pencegahan mastitis dari luar sedangkan suplemen temulawak adalah pengobatan mastitis dari dalam tubuh. Hal tersebut diharapkan mampu mempercepat proses penyembuhan mastitis atau perbaikan sel epitel pada ambing yang mengakibatkan kesembuhan kuartir ambing (Riyanto et al. 2016). Penelitian ini untuk mengkaji pengaruh pemberian suplemen dan antiseptik teat dipping temulawak terhadap konsumsi pakan dan produksi susu sapi perah penderita mastitis subklinis.

\section{MATERI DAN METODE}

Penelitian dilaksanakan pada Januari Februari 2019 di UD Wahyu Agung Desa Sumogawe, Kecamatan Getasan, Kabupaten Semarang. Analisis sampel pakan dilakukan di Laboratorium Ilmu Nutrisi dan Pakan Fakultas Peternakan dan Pertanian Universitas Diponegoro.

Materi penelitian adalah 12 ekor sapi Friesian Holstein (FH) penderita mastitis subklinis laktasi ke 3-5 dan bulan laktasi ke 5-6 dengan rata-rata bobot badan 466,49 $\pm 44,99$ (CV $=9,75 \%) \mathrm{kg}$ dan rata-rata produksi susu awal $6,90 \pm 2,70(\mathrm{CV}=39,34 \%)$ liter. Bahan yang digunakan yaitu tepung temulawak (Curcuma xanthorriza Roxb), gliserin dan aquades. Pakan basalberupa hijauan, konsentrat komersil (Wahyu Agung Feed) dan komboran. Hijauan terdiri dari rumput Kolonjono dan tebon (perbandingan 50\% : 50\%), komboran I terdiri dari campuran bekatul, kulit kacang, kulit kopi dan ampas tahu dan komboran II terdiri dari ampas tahu dan konsentrat. Peralatan yang digunakan botol kaca, botol dipping, gelas ukur berskala, timbangan gantung, timbangan analitis, kantong plastik, ember dan karung.

Penelitian dilakukan melalui empat tahapan, yaitu rancangan penelitian, tahap pra penelitian, tahap penelitian dan analisis data.

\section{Rancangan Penelitian}

Rancangan penelitian yang digunakan adalah rancangan acak kelompok (RAK) yang terdiri dari 4 perlakuan dan 3 kelompok. Pengelompokkan didasarkan produksi susu yaitu rendah, sedang dan tinggi. Adapun perlakuan yang diterapkan yaitu:

$$
\begin{gathered}
\mathrm{T}_{0}=\text { Pakan basal (tanpa perlakuan) } \\
\mathrm{T}_{1}=\mathrm{T}_{0}+\text { suplemen temulawak } 1 \% \\
\quad \text { kebutuhan BK } \\
\mathrm{T}_{2}=\mathrm{T}_{0}+\text { antiseptik teat dipping temulawak } \\
\mathrm{T}_{3}=\mathrm{T}_{0}+\text { suplemen temulawak } 1 \% \\
\quad \begin{array}{c}
\text { kebutuhan } \mathrm{BK}+\text { antiseptik teat } \\
\text { dipping temulawak }
\end{array}
\end{gathered}
$$

\section{Tahap Pra Penelitian}

Tahap persiapan meliputi pemilihan ternak, persiapan tepung temulawak,pembuatan antiseptik teat dipping dan identifikasi pakan. Pemilihan ternak dilakukan dengan melakukan 
pengujian mastitis dengan metode CMT. Pengujian CMT yaitu uji kualitas susu menggunakan reagen CMT pada masing-masing puting sapi,dan melakukan pengumpulan data identitas ternak meliputi bobot badan, periode laktasi, bulan laktasi dan produksi susu. Pembuatan antiseptik teat dipping dilakukan dengan metode perebusan yaitu $95 \mathrm{ml}$ aquades dimasak hingga mendidih kemudian ditambahkan $5 \mathrm{~g}$ tepung temulawak dan diaduk. Setelah homogen dimasak kembali hingga mendidih, didiamkan beberapa saat lalu dimasukkan ke dalam botol kaca dan digojok. Teat dipping ditambahkan $50 \mathrm{ml}$ gliserin dan digojok agar homogen, lalu disimpan di botol dipping. Pakan yang digunakan berupa hijauan, konsentrat komersial (WA Feed) dan komboran yang diberikan setiap pagi dan sore hari. Kadar nutrien dan susunan ransum disajikan dalam Tabel 1. dan Tabel 2. berdasarkan hasil analisis di Laboratorium Ilmu Nutrisi dan Pakan, Fakultas Peternakan dan Pertanian Universitas Diponegoro Semarang.

Tabel 1. Hasil analisis proksimat pakan

\begin{tabular}{|c|c|c|c|c|c|c|c|c|}
\hline \multirow{2}{*}{ Bahan Pakan } & \multicolumn{8}{|c|}{ Kandungan Nutrien } \\
\hline & Air $^{1)}$ & $\mathrm{BK}^{1)}$ & $\mathrm{Abu}^{1)}$ & $\mathrm{LK}^{1)}$ & $\mathrm{SK}^{1)}$ & $\mathrm{PK}^{1)}$ & BETN $^{2)}$ & $\mathrm{TDN}^{3)}$ \\
\hline & & & & & 7) ----- & & ------- & \\
\hline Hijauan & 79,87 & 20,13 & 10,11 & 2,02 & 39,71 & 6,70 & 41,46 & 48,55 \\
\hline Komboran I & 69,50 & 30,50 & 5,79 & 5,17 & 28,46 & 10,38 & 50,19 & 62,23 \\
\hline Komboran II & 69,28 & 30,72 & 5,01 & 5,16 & 17,64 & 12,51 & 59,68 & 68,73 \\
\hline Wahyu Agung Feed & 16,32 & 83,68 & 11,80 & 2,01 & 17,99 & 7,08 & 61,12 & 58,77 \\
\hline Temulawak & 15,22 & 84,78 & 6,12 & 0,67 & 14,12 & 7,67 & 71,42 & 69,89 \\
\hline
\end{tabular}

Keterangan:

1) Hasil analisis proksimat yang dilakukan di Laboratorium Ilmu Nutrisi dan Pakan, Fakultas Peternakan dan Pertanian Universitas Diponegoro, Semarang (2019)

2) Berdasarkan perhitungan dengan rumus (Anggorodi, 1995)

$\mathrm{BETN}=100 \%-(\mathrm{Abu}+\mathrm{LK}+\mathrm{SK}+\mathrm{PK})$

3) Berdasarkan perhitungan dengan rumus (Sutardi, 2001)

$\mathrm{TDN}=70,6+0,259 \mathrm{PK}+1,01 \mathrm{LK}-0,760 \mathrm{SK}+0,0991 \mathrm{BETN}$

Tabel 2. Susunan ransum dan kadar nutrien yang diberikan

\begin{tabular}{|c|c|c|c|c|}
\hline Bahan Pakan & T0 & $\mathrm{T} 1$ & $\mathrm{~T} 2$ & $\mathrm{~T} 3$ \\
\hline Komposisi & \multicolumn{4}{|c|}{--o- } \\
\hline Hijauan & 32,56 & 32,36 & 32,56 & 32,35 \\
\hline Komboran I & 39,46 & 39,22 & 39,46 & 39,21 \\
\hline Komboran II & 9,94 & 9,88 & 9,94 & 9,87 \\
\hline Konsentrat Wahyu Agung Feed & 18,05 & 17,94 & 18,05 & 17,93 \\
\hline Temulawak & - & 0,60 & - & 0,64 \\
\hline Jumlah & 100 & 100 & 100 & 100 \\
\hline \multicolumn{5}{|l|}{ Kadar Nutrien } \\
\hline $\mathrm{Abu}(\%)^{1)}$ & 8,20 & 8,19 & 8,20 & 8,19 \\
\hline $\operatorname{LK}(\%)^{1)}$ & 3,57 & 3,56 & 3,57 & 3,55 \\
\hline $\mathrm{SK}(\%)^{1)}$ & 29,16 & 29,07 & 29,16 & 29,06 \\
\hline PK $(\%)^{1)}$ & 8,80 & 8,79 & 8,80 & 8,79 \\
\hline $\operatorname{BETN}(\%)^{2)}$ & 50,27 & 50,39 & 50,27 & 50,40 \\
\hline TDN $(\%)^{3)}$ & 59,62 & 59,69 & 59,62 & 59,69 \\
\hline
\end{tabular}

Keterangan:

1) Hasil analisis proksimat yang dilakukan di Laboratorium Ilmu Nutrisi dan Pakan, Fakultas Peternakan dan Pertanian Universitas Diponegoro, Semarang (2019)

2) Berdasarkan perhitungan dengan rumus (Anggorodi, 1995)

$\mathrm{BETN}=100 \%-(\mathrm{Abu}+\mathrm{LK}+\mathrm{SK}+\mathrm{PK})$

3) Berdasarkan perhitungan dengan rumus (Sutardi, 2001)

$\mathrm{TDN}=70,6+0,259 \mathrm{PK}+1,01 \mathrm{LK}-0,760 \mathrm{SK}+0,0991 \mathrm{BETN}$ 
Tahap Penelitian

Perlakuan yang diterapkan yaitu pemberian suplemen dan teat dipping temulawak. Suplemen temulawak dicampurkan pada konsentrat sebanyak 1\% kebutuhan BK diberikan setiap pagi dan sore sedangkan teat dipping temulawak diberikan setiap pagi (04.00 WIB) dan sore (14.00 WIB) setelah pemerahan dengan mencelupkan puting selama 10 detik. Perlakuan diterapkan selama 30 hari dengan pengambilan data meliputi konsumsi pakan dan produksi susu. Konsumsi pakan diukur dengan menghitung selisih antara pakan yang diberikan dikurangi dengan pakan sisa. Pakan yang diberikan dan pakan sisa diambil sampel kemudian dilanjutkan dengan analisis bahan kering untuk memperoleh data bahan kering pakan dan bahan kering pakan sisa. Perhitungan konsumsi bahan kering (BK) dengan cara berikut :

Konsumsi BK $=$ [pakan pemberian $\mathrm{x} \% \mathrm{BK}$ pakan pemberian $]-[$ sisa pakan $\mathrm{x} \% \mathrm{BK}$ sisa pakan $]$.

Data produksi susu diperoleh dengan cara mencatat produksi sususetiap pemerahan pagi dan sore. Pengukuran dilakukan menggunakan gelas ukur berskala.

\section{Analisis Data}

Data konsumsi pakan dan produksi susu yang diperoleh dianalisis menggunakan analisis ragam (ANOVA atau analysis of variance) berdasarkan rancangan acak kelompok dengan taraf signifikasi 5\%. Apabila hasil ANOVA menunjukkan pengaruh nyata dari perlakuan, maka dilanjutkan dengan uji jarak berganda Duncan untuk mengetahui perbedaan nilai tengah antar perlakuan.

\section{HASIL DAN PEMBAHASAN}

\section{Konsumsi Pakan Sapi Perah Mastitis Subklinis}

Rataankonsumsi pakan sapi perah mastitis subklinis akibat suplemen dan antiseptik teat dipping temulawak disajikan padaTabel 3 .

Berdasarkan Tabel 3. dapat diketahui bahwa rata-ratakonsumsi $\mathrm{BK} \mathrm{T}_{0}$ sebesar $18,15 \pm$ $0,12 \mathrm{~kg} \mathrm{BK}, \mathrm{T}_{1}$ sebesar 18,21 $\pm 0,18 \mathrm{~kg} \mathrm{BK}, \mathrm{T}_{2}$ sebesar 17,98 $\pm 0,29 \mathrm{~kg} \mathrm{BK}$ dan $\mathrm{T}_{3}$ sebesar 18,17 $\pm 0,13 \mathrm{~kg}$ BK . Hasil analisis menunjukkan bahwa perlakuan suplemen dan antiseptik teat dipping temulawak tidak memberikan pengaruh yang nyata terhadap konsumsi BK. Pengaruh tidak nyata akibat perlakuan diduga karena kandungan senyawa aktif dalam temulawak tidak bekerja dengan optimal. Penelitian Indriani et al. (2013) menunjukkan bahwa suplementasi temulawak $2 \%$ dalam ransum meningkatkan konsumsi bahan kering sapi perah laktasi.

Sapi perah yang menderita mastitis akan mengalami perubahan $\mathrm{pH}$ dalam rumen sehingga keseimbangan mikroba rumen terganggu. Pemberian perlakuan tidak berpengaruh diduga karena adanya $\mathrm{pH}$ di dalam rumen mengalami perubahan. Nurdin (2007) menyatakan bahwa mastitis mengganggu aktivitas mikroba rumen dan yang berkembang lebih ke arah mikroba patogen. Hasil penelitian sesuai dengan Harjanti et al. (2019) bahwa sapi mastitis yang diberi campuran herbal temulawak pada ransum tidak mempengaruhi mikroba proteolitik di dalam rumen sehingga tidak mempengaruhi konsumsi.

\section{Produksi SusuSapi Perah Mastitis Subklinis}

Berdasarkan Tabel 3. dapat diketahui bahwa rata-rataproduksi susu $\mathrm{T}_{0}$ sebesar 7,55 \pm 0,96 liter/hari, $\mathrm{T}_{1}$ sebesar 7,01 $\pm 2,67$ liter/hari, $\mathrm{T}_{2}$ sebesar 5,74 \pm 4,06 liter/hari dan $\mathrm{T}_{3}$ sebesar $5,90 \pm 1,57$ liter/hari. Hasil analisis menunjukkan bahwa perlakuan suplemen dan antiseptik teat dipping temulawak tidak memberikan pengaruh yang nyata terhadap produksi susu.

Produksi susu pada masing-masing perlakuan tidak menunjukkan pengaruh yang nyata, diakibatkan konsumsi BK pakan (Tabel 1) menunjukkan hasil yang tidak berbeda nyata pula. Hal ini berarti bahwa nutrisi pakan yang dikonsumsi untuk membentuk komponen susu juga relatif sama.

Tabel 3. Rataan konsumsi pakan dan produksi susu sapi perah mastitis subklinis

\begin{tabular}{lcccc}
\hline \multicolumn{1}{c}{ Variabel } & $\mathrm{T}_{0}$ & $\mathrm{~T}_{1}$ & $\mathrm{~T}_{2}$ & $\mathrm{~T}_{3}$ \\
\hline Konsumsi pakan (kg BK) & $18,15 \pm 0,12$ & $18,21 \pm 0,18$ & $17,98 \pm 0,29$ & $18,17 \pm 0,13$ \\
Produksi susu (1/hari) & $7,55 \pm 0,96$ & $7,01 \pm 2,67$ & $5,74 \pm 4,06$ & $5,90 \pm 1,57$ \\
\hline
\end{tabular}


Utomo dan Miranti (2010) menyatakan bahwa konsumsi bahan kering akan berpengaruh pada tercukupinya kebutuhan nutrisi pakan yang akan digunakan untuk memenuhi kebutuhan pertumbuhan, reproduksi dan produksi.

Teat dipping tidak berpengaruh terhadap produksi susu karena dipping merupakan tindakan yang bersifat preventif dalam pengobatan mastitis. Penelitian Mahpudin et al. (2017) menunjukkan bahwa dipping dengan ekstrak daun Babadotan tidak menunjukkan pengaruh yang nyata terhadap produksi susu. Didukung oleh Asror et al. (2017) bahwa teat dipping yang dari ekstrak daun ubi jalar merah menunjukkan tidak adanya perbedaan karena dipping hanya berperan sebagai pencegahan mastitis.

Kurkuminoid yang terkandung dalam temulawak belum berfungsi secara optimal. Zat kurkuminoid menurut Raharjo (2010) dan Riyanto et al. (2016) berfungsi sebagai antibakteri yang dapat melindungi membran sel kelenjar ambing dari infeksi bakteri. Temulawak yang digunakan sebagai teat dipping diduga hanya melapisi bagian luar puting dan mencegah bakteri patogen masuk dalam puting sehingga kurang optimal dalam membantu proses penyembuhan sel epitel pada alveoli kelenjar susu serta kuartir ambing. Hal ini dibuktikan dengan hasil penelitian Agustina et al. (2019) bahwa kombinasi pemberian temulawak sebagai teat dipping dan suplemen pakan menunjukkan signifikansi pada perhitungan sel somatik yaitu H0 sebesar $28,30 \times 10^{5} \mathrm{sel} / \mathrm{ml}$, H15 sebesar 11,79 x $10^{5} \mathrm{sel} / \mathrm{ml}$ dan H30 sebesar 13,07 x $10^{5} \mathrm{sel} / \mathrm{ml}$. Nilai tersebut masih diatas standar normal jumlah sel somatik pada susu. SNI 3141 (2011) menyebutkan bahwa nilai maksimum jumlah sel somatik pada susu segar adalah $4 \times 10^{5} \mathrm{sel} / \mathrm{ml}$. Jumlah sel somatik menggambarkan tingkat peradangan ambing sapi penderita mastitis, sehingga semakin sedikit jumlah sel somatik menandakan bahwa mastitis berangsur sembuh.

\section{KESIMPULAN}

Simpulan dari penelitian ini adalah penambahan suplemen temulawak sebanyak $1 \%$ kebutuhan BK dan antiseptik teat dipping temulawak belum mampu meningkatkan konsumsi BK dan produksi susu sapi perah laktasi penderita mastitis subklinis.

\section{UCAPAN TERIMAKASIH}

Terimakasih disampaikan kepada Universitas Diponegoro yang telah mendanai penelitian melalui Program Hibah Penelitian UNDIP Tahun 2018.

\section{DAFTAR PUSTAKA}

Alipin, K., R. Safitri dan R. Kartasudjana. 2016. Suplementasi probiotik dan temulawak pada ayam pedaging terhadap populasi Salmonella $s p$ dan kolesterol darah. Jurnal Veteriner 17 (4) :1-5.

Asror, M. Z., E. Wulandari, T. Suselowati, D. A. Solehah dan D. W. Harjanti. 2017. Efektivitas ekstrak daun ubi jalar merah sebagai antiseptik teat dipping untuk sapi perah mastitis subklinis. Prosiding Seminar Teknologi dan Agribisnis Peternakan VI. Fakultas Peternakan Universitas Jendral Soedirman. 7 Juli 2018. Hal. 341-346.

Harjanti, D. W., F. Wahyono and D. N. Afifah. 2019. Milk production and milk quality of sub-clinical mastitis cows feed with different supplementation of herbal in the diet. IOP Conference Series : Earth and Environmental Science. International Conference on Sustainable Agriculture for Rural Development. Purwokerto, Indonesia. 23-24 Oktober 2018. Hal. 1-5.

Harjanti, D. W., R. Ciptaningtyas, F. Wahyono dan E. T. Setiatin. 2018. Isolation and Identification of Bacterial Pathogen From Mastitis Milk in Central Java Indonesia. IOP Conference Series : Earth and Environmental Science. International Symposium on Food and Agrobiodiversity (ISFA). Semarang, Indonesia. 26-27 September 2017.

Indriani, A. P., A. Muktiani dan E. Pangestu. 2013. Konsumsi dan produksi protein susu sapi perah laktasi yang diberi suplemen temulawak (Curcuma xanthorriza) dan seng proteinat. Jurnal Animal Agriculture 2 (1) :128-135.

Lucy, J., L. Florencia, Elvina, D. Stefani dan A. I. Susanti. 2017. Efek pemberian temulawak terhadap berat badan dan 
sistem imun mencit BALB/c. Jurnal Sains dan Teknologi 1 (1) : 32-50.

Mahpudin, F. Wahyono dan D. W. Harjanti. 2017. Efektivitas ekstrak daun Babadotan sebagai green antiseptic untuk pencelup puting sapi perah. Jurnal Agripet 17 (1) : 15-23.

Nurdin, E. 2007. Pengaruh pemberian tongkol bunga matahari (Helianthus annus L.) dan probiotik terhadap penurunan derajat mastitis pada sapi perah Fries Holland penderita mastitis subklinis. J. Intern. Trop. Anim. Agric. 32 (2) :76-79.

Pusat Data dan Sistem Informatik Pertanian. 2017. Outlook Susu Komoditas Pertanian Subsektor Peternakan. Kementerian Pertanian Indonesia, Jakarta.

Rahardjo, M. 2010. Penerapan SOP budidaya untuk mendukung temulawak sebagai bahan baku obat potensial. Perspektif 9 (2) :78-93.
Riyanto, J., Sunarto, B. S. Hertanto, M. Cahyadi, R. Hidayah dan W. Sejati. 2016. Produksi dan kualitas susu sapi perah penderita mastitis yang mendapat pengobatan antibiotik. Jurnal Sains Peternakan 14 (2) :30-41.

Standar Nasional Indonesia (SNI) Nomor 3141. 2011. Tentang Syarat Mutu Susu Segar. Badan Standarisasi Nasional, Jakarta.

Sutardi, T. 2001. Revitalisasi Peternakan Sapi Perah Melalui Penggunaan Ransum Berbasis Limbah Perkebunan dan Suplementasi Mineral Organik. Lembaga Penelitian dan Pengabdian Masyarakat Institut Pertanian Bogor, Bogor.

Utomo, B dan D. P. Miranti. 2010. Tampilan produksi susu sapi perah yang mendapat perbaikan manajemen pemeliharaan. Caraka Tani 25 (1) :21-25. 